\title{
CERRADO FORESTS: SEASONAL FOREST AND CERRADÃO
}

Thalles Oliveira Martins ${ }^{1}$, Fernanda Duarte Araujo ${ }^{2}$, Karoline Nascimento Siqueira ${ }^{2}$, Anna Clara Chaves Ribeiro², Carlos de Melo e Silva-Neto ${ }^{3 *}$,

1 University of Brasilia, Brazil.

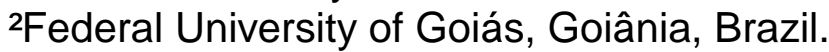

${ }^{3}$ Federal Institute of Education, Science and Technology of Goiás, City of Goiás,

Brazil. *carloskoa@gmail.com

Recebido em: 05/12/2016 - Aprovado em: 15/12/2016 - Publicado em: 31/12/2016 DOI: 10.18677/Agrarian_Academy_2016b21

\begin{abstract}
The Cerrado biome presents different physiognomies distributed throughout several Brazilian states. Studies related to species distribution as direct environmental factors may subsidize forest restoration projects. The objective of this study wasto evaluate ecological and structural differences and determine the species distribution based on soil factors in two physiognomies types of Cerrado. Data sampling was conducted in the area of influence of the sugar cane industry in southwest of Goiás, Brazil. Soil samples were collected in those plots and analyzed chemically and psysically. The results of the soil characteristics were useful to verify if the species distribution correlate with soil patterns through canonical components analysis (CCA). The structural aspects were higher in the plots identified as seasonal forest. Although the Ecological aspects, such as species diversity, were higher in the cerradão. The CCA showed a positive correlation between the tree species distribution with physicochemical characteristics of soil. The analysis showed a positive correlation between the distribution of tree species and the physicochemical characteristics of the soil. A group of species was related to higher fertility in the soil and clay content. Another group was correlated with low fertility and higher sand content soils.
\end{abstract}

KEYWORDS: Seasonal Forest, cerradão, multivariate analysis,soil, vegetation.

\section{FLORESTAS DO CERRADO: FLORESTA ESTACIONAL E CERRADÃO}

\section{RESUMO}

O Cerrado é um bioma que apresenta diferentes fitofisionomias que estão distribuídas em vários estados brasileiros. Estudos de como estão distribuídas as espécies relacionadas a fatores ambientais darão subsídios para futuros projetos de recuperação. O objetivo do estudo foi avaliar as diferenças nos aspectos estruturais, ecológicos e analisar a distribuição de espécies relacionadas a fatores edáficos, em duas diferentes fitofisionomias do Cerrado. As fitofisionomias foram a Floresta Estacional e o Cerradão.O levantamento de dados ocorreu na zona de influência de uma indústria sucroalcooleira no sudoeste goiano.Foram feitas análises físicoquímicas das amostras de solos coletadas nas parcelas. O levantamento das características dos solos serviu pra verificar, através da análise de componentes AGRARIAN ACADEMY, Centro Científico Conhecer - Goiânia, v.3, n.06; p.1 2016 
canônicos (CCA), a distribuição de espécies correlacionadas às características edáficas. Os aspectos estruturais foram superiores nas parcelas identificadas como Floresta Estacional. Aspectos ecológicos, como diversidade de espécies, foram superiores no Cerradão. A análise demonstrou correlação positiva entre a distribuição de espécies arbóreas e as características físico-químicas do solo. Um grupo de espécies foram relacionados a maior fertilidade no solo e teor de argila. Outro grupo foi correlacionado com solos de baixa fertilidade e maiores teores de areia.

PALAVRAS-CHAVE: Análise multivariada, Cerradão, Floresta Estacional, solo, vegetação.

\section{INTRODUCTION}

The Cerrado biome is composed of different phytophysiognomies divided into forest, savanna and grassland formations (RIBEIRO \& WALTER, 2008). Such phytophysiognomies are distributed according to variations of the environment in which they are inserted.The main edaphic factors involved in the distribution of phytophysiognomies are: soil depth, natural fertility levels, soil aluminum content, water saturation of subsurface and superficial soil layers (MARIMON \& HARIDASAN, 2005).

With an approximate area of 2 million $\mathrm{km}^{2}$ (IBGE 2004), it is considered as one of the global biodiversity hotspot. Are areas of high biodiversity and are threatened by human activities (MYERS et al., 2000; SILVA \& BATES, 2002). However, a study carried out in 2015 on land use and soil cover shows that approximately $54 \%$ of native vegetation cover remains. Being the main anthropic activities involved in the occupation of the natural space, agriculture and livestock. Especially the advancement of grain planting area and sugarcane (BRASIL, 2015). The pressure on forest remnants caused by large industrial and monoculture makes necessary detailed studies of ecological characteristics and species distribution. Even because they will provide subsidies for future recovery plans for areas degraded by monoculture agronomic crops. Based on this study and others in the scientific literature, the management and recovery plans will try to approach the original. Do not plant species that de-characterize the biome. The vegetation components are directly related to soil characteristics, which is a key element to plant life, it is responsible for providing water and nutrients required by plants.

According to LOPES \& GUILHERME (1992), the soils of the cerrado are basically highly weathered and Podzolic soils, have low natural fertility, and are acid soils that have low nutrient availability and high saturation for aluminum (m\%) as well. Such as high phosphorus fixation capacity. Aluminum, in acid soils, is one of the main responsible for the low productivity of the crops, being a limiting factor to the growth of the plants. The most obvious symptom of the harmful effect of toxic levels of aluminum is the reduction in root growth of susceptible plants, which avoid the plant from obtaining water and nutrients in depth by its superficial rooting. Effective depth, drainage, presence of profile concretions, groundwater depth and soil fertility are considered to be the main determinants of plant diversity (MARIMON \& HARIDASAN, 2005).

Nowadays it is possible to know some of the main floristic patterns in common for these two phytophysiognomies in the biome (OLIVEIRA-FILHO et al., 2006), however, it is still unknown how these two formations diverge floristically from each other. Investigations of this order are necessary to understand basic aspects for a 
correct classification of these phytophysiognomies and to take effective measures for conservation, since these forest types that have a great phytodiversity in the biome (WALTER, 2006), are on a high degree of disturbance (SILVA et al. 2006). The changes occurring in the Cerrado brought major environmental damage fragmentation of habitats, extinction of biodiversity, invasive exotic species, soil erosion, aquifer pollution, ecosystem degradation, changes in burning regimes, imbalances in the carbon cycle and regional climate changes (RIBEIRO \& WALTER, 2008). Therefore, it is necessary to increase the knowledge related to its characteristics, mainly to know how to preserve and maintain what still exists. Thus, the objective of the work is to analyze the ecological, edaphic, vertical, and horizontal structure of the Cerrado and Seasonal Forest phytophysiognomies in the Cerrado of Chapadão do Céu, Goiás.

\section{MATERIAL AND METHODS}

The study was conducted between August 6-12, 2015 in the drought period and January 24 to 31,2016 in the rainy season, at 12 pre-established points in Chapadão do Céu, Goiás. The collections at two different seasons in the year do not influence the sampled richness, but it aids in the identification of botanical species, since it increases the possibility of finding fertile botanical material (flower and / or fruit). The points were marked in tree remnants of the Cerrado and Seasonal Forest phytophysiognomy, using the geographical coordinates of the Garmin e-trex GPS. The points had their phytophysiognomy confirmed according to RIBEIRO and WALTER (2008) and listed the main plant species. Points in the area are in: here.

For the survey and identification of the botanical species at the points marked, twelve plots of $20 \times 30 \mathrm{~m}^{2}$ were marked; totaling $600 \mathrm{~m}^{2}$ per plot and $7,200 \mathrm{~m}^{2}$ of sampled area. The CAP (Height of the Chest) was measured (Figure 10, 11 and 12) and Height of all trees with inclusion limits higher than $22 \mathrm{~cm}$ within the plots, besides identifying the tree species, collecting all flowering botanical material, besides the identification of other materials, whether in a vegetative state of growth.

The botanical material not identified in the field was collected, harbored and taken to the Federal University of Goiás for identification with specialists of each botanical family, besides botanical identification key (BARROSO et al., 1991). The botanical material was pressed and made exsiccate, to deposit in the Herbarium of the Botanic Garden Amália Hermano Teixeira de Goiânia.

To check the soil relations with the state of the forest soil were collected from 0 to $10 \mathrm{~cm}$ depth at three points at random. The soil was conditioned and taken for analysis of texture and chemical fertility (FELIZOLA et al., 2006). To scale the size of the forest fragments, they had their measured area with Google Earth PRO help. The condition of isolated (fragmented) or continuous fragment was also considered (Adapted from CABACINHA \& CASTRO, 2010).

\section{STATISTICAL ANALYSIS}

For the statistical analysis of the data, phytosociological analyzes were performed, observing frequency, density, dominance, basal area and index of value of importance by plots sampled (FREITAS \& MAGALHÃES, 2012). Similarity matrices and clustering dendrograms were obtained through the Euclidean distance, using the PAST 2.7 program. For the wealth estimation, the Jack-knife method was used, which estimates the total richness using the number of species that occur in only one sample (uniques). This measure makes it possible to estimate the total number of species in a given community from the sample data. 
Ecological parameters such as abundance, species richness and diversity of Richness, Individuals, Dominance, Simpson Dominance, Shannon-Wiener Diversity $(\mathrm{H} ')$ and Equitability were calculated using the PAST program 2.7. To check the health of the structure of the tree assembly in the area were carried out frequency distributions of height; circumference and area of basal plant measured per plot, and checked their distribution pattern and enabling comparison with other areas and future long-term studies (SILVA-NETO et al., 2015; MARTINS et al., 2016). To relate the soil characteristics with the fragments, abundance and richness of forest species was carried out analysis of the canonical components (SIQUEIRA et al., 2016; VENTUROLI et al., 2015).

\section{RESULTS}

Among the ecological characteristics that stood out in this monitoring is the mortality of trees. For the areas of Cerradão, tree mortality remained relatively low, with up to five dead species per plot sampled. As for the seasonal forest, mortality was found up to 16 trees, which can be considered high for the area. Future relationships between fragment size and soil use approximately the fragment should be sought to elucidate possible causes for the high mortality of the trees in fragments of seasonal forests.

The areas near the edge end up becoming brighter, warmer and drier, and species respond in many ways to this phenomenon. Some species do not support low moisture, for example, but others end up benefiting, such as some species of vines that have large abundance in the fragment (SILVA-NETO et al., 2015; VENTUROLI et al., 2015). Thus, the natural balance is compromised; there may be great loss of species richness of variation and differentiation of the basal area of the species found on the edge and inside the fragment.

TABLE 1 Structural and ecological aspects of the vegetation in the points sampled in the area of influence of the Chapadão do Céu, Goiás (S - Richness, A - Abundance, D - Dominance, S - Simpson, H '- Shannon, E' Equitability, M - Mortality; Frag - Fragment size; $\mathrm{H}$ average - average height of trees; $A B$ - base area; estimated volume of wood).

\begin{tabular}{cccccccccccc}
\hline Fito & $\mathbf{S}$ & $\mathbf{A}$ & $\mathbf{D}$ & $\mathbf{S}$ & $\mathbf{H}^{\prime}$ & $\mathbf{E}$ & $\mathbf{M}$ & $\begin{array}{c}\text { Frag } \\
\text { (ha) }\end{array}$ & $\begin{array}{c}\text { Hmean } \\
(\mathbf{c m})\end{array}$ & $\begin{array}{c}\mathbf{A B} \\
\left(\mathbf{c m}^{2}\right)\end{array}$ & $\begin{array}{c}\text { Vol } \\
\left(\mathbf{m}^{\mathbf{3}}\right)\end{array}$ \\
\hline $\mathrm{CE}$ & 28 & $\begin{array}{c}116, \\
17\end{array}$ & 0,10 & 0,89 & 2,81 & 0,85 & 2 & 541,92 & 375,95 & 0,01 & 3,42 \\
ME & 14 & 77 & 0,20 & 0,79 & 2,07 & 0,77 & $\begin{array}{c}7,8 \\
3\end{array}$ & 118,05 & 804,85 & 0,02 & 11,75 \\
\hline
\end{tabular}

The size and shape of a fragment are linked directly to the size of the border. The smaller the fragment or more elongated, the more strongly the edge effects can be felt, because it decreases the ratio between interior and extremity. Forest clearings around the fragment may represent a barrier to many species adapted to live within forests, which prevents the flow of individuals between the fragments, and may eventually decrease the genetic variability of these populations (FRANSCESCHINELLI et al., 2015, MELO et al., 2015)

Knowing the species that develop in edges and interior of forest fragments is relevant to the understanding of the structure of the forest community. This understanding of the structure of the forest can aid in the restoration/recovery 
processes of degraded areas, besides actions that encourage the connection between forest fragments to minimize edge effects.

Patterns in the distribution of the structural features of the Chapadão do Céu tree assemblage demonstrate the moment when the plant community is passing and may show previous changes, such as fires, irregular deforestation, edge effects and others. In addition to outlining a current scenario for future comparison of the area (FELFILI \& VENTUROLI, 2000; SILVA-NETO et al., 2015, VENTUROLI, 2015).

The height, basal area, and volume may indicate if the amount of individuals with a particular characteristic is a natural pattern for a particular environment, or has been conditioned by some anthropogenic change. For the height characteristic, in the areas of seasonal forest is within the normal distribution, presenting the expected pattern for seasonal forest, with more individuals of average height (between eight and ten meters in height) and few with lower height (below three $\mathrm{m}$ Height) and great height (above 15m in height) (Figure 1). The diameter at the mean chest height for the forest presents an inverted $J$ curve pattern, which is expected for a growing forest tending to climax, presenting new individuals in the form of seedlings and regrowth.
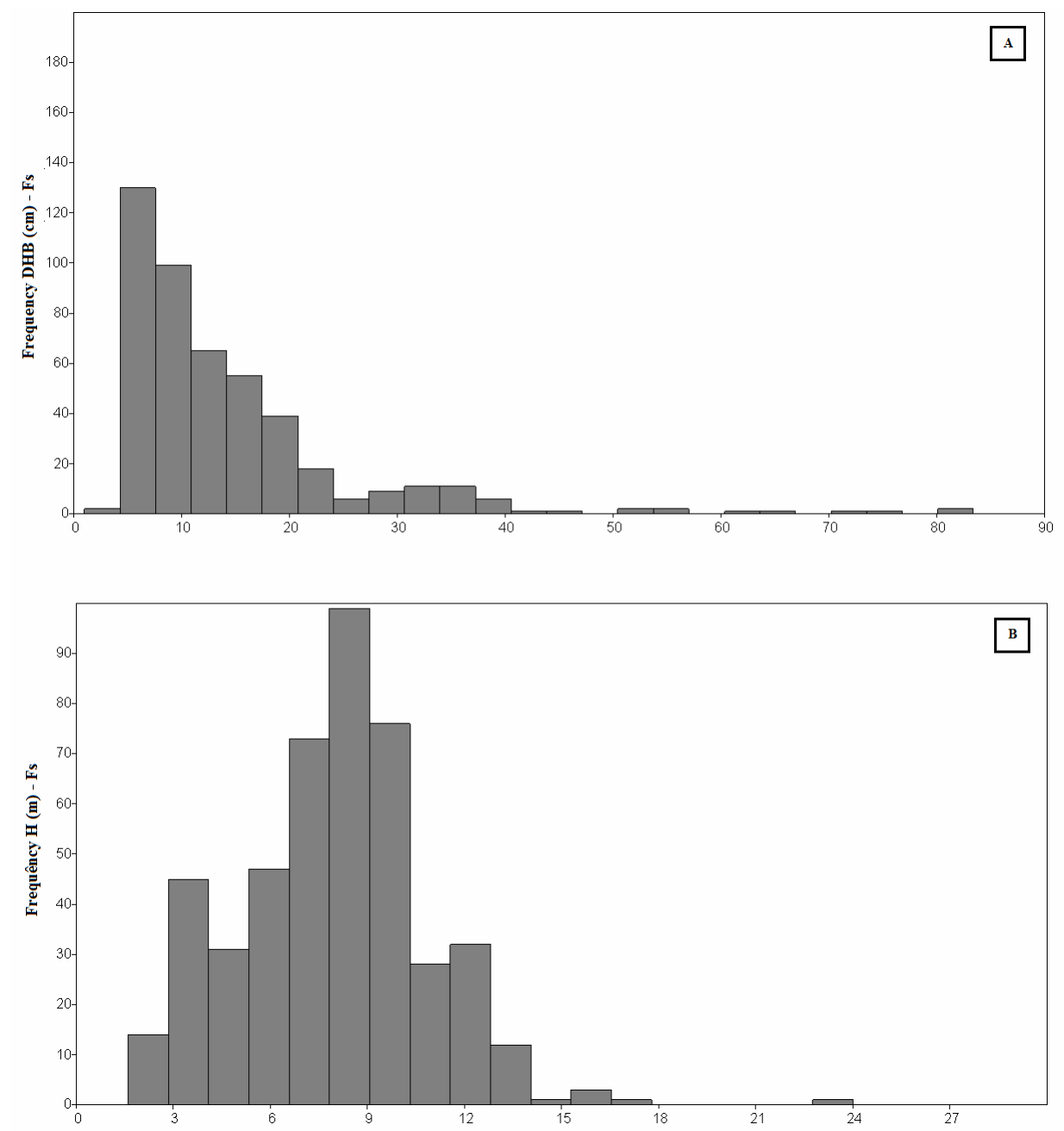

FIGURE 1 Distribution of the $\mathbf{A}$. frequencies of the diameters at the height of the chest and $\mathbf{B}$. heights of the trees in different plots of Seasonal Forest (ME) in the area of influence of the enterprise in Chapadão do Céu, Goiás. 
For the formation of Cerradão (Figure 2), the distribution of individuals with diameter at collection height $(30 \mathrm{~cm}$ of soil) also showed the inverted $\mathrm{J}$ pattern, indicating vegetation growth. On the other hand, the distribution in height showed many individuals in the lower classes, and may indicate the occurrence of an earlier event that stimulated the entry of new individuals (regeneration, regrowth, new germination), in addition to indicating that Cerradão presents many less dense areas, with greater light input, which further stimulates the appearance of new individuals in the fragment.
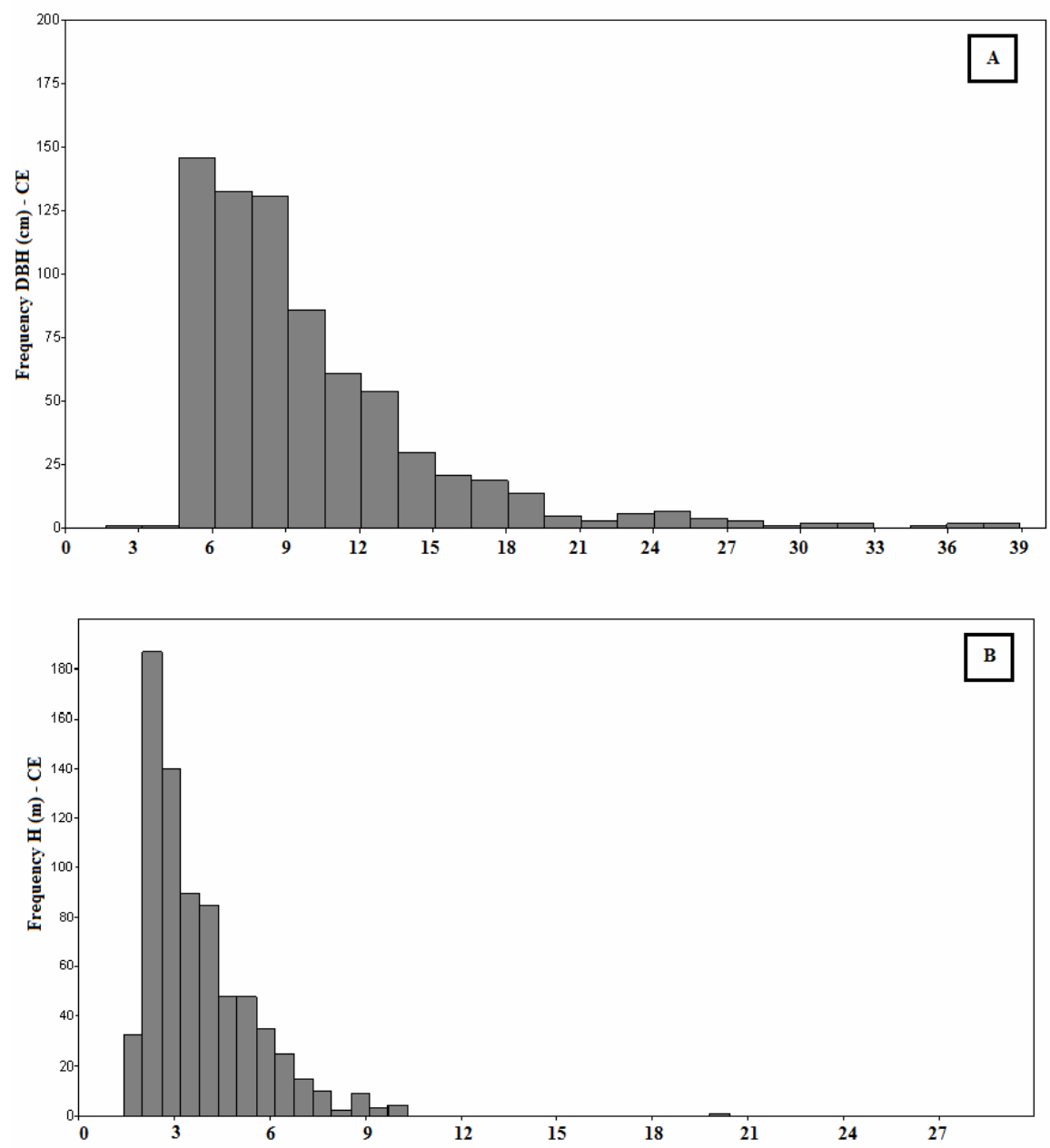

FIGURE 2 Distribution of the $\mathbf{A}$. frequencies of the diameters at the height of the chest and the B. heights of the trees in different plots of Cerradão (CE) in the area of influence of the enterprise in Chapadão do Céu, Goiás

The pedological characteristics of the soils of the region, along with the structural and ecological characteristics of the forest fragments, show that Cerradão presented the largest forest fragments, also containing the greatest abundance and richness of species, even with the poorest soils in fertility. Already the seasonal forests soils showed a higher amount of nutrients as well as increased production of biomass based area, timber volume and plant height. The mortality of trees was accentuated in the seasonal forest, in relation to the amount of potassium $(K)$ in the soil. This relationship may indicate old burnings and forest fires, which turn biomass into ash, which is rich in potassium. 
These same fires that would cause damage to the seasonal forest that would take the plants to death. The seasonal forest, unlike Cerradão and "Cerrado stricto sensu", does not present direct adaptations to resist the passage of fire, such as coarse bark and seasonal loss of foliage. Thus, once burned, the trees die directly or weaken and can lead to death in the long term (one year to five years) (FELFILI, 2003; CAMARGOS et al., 2010).

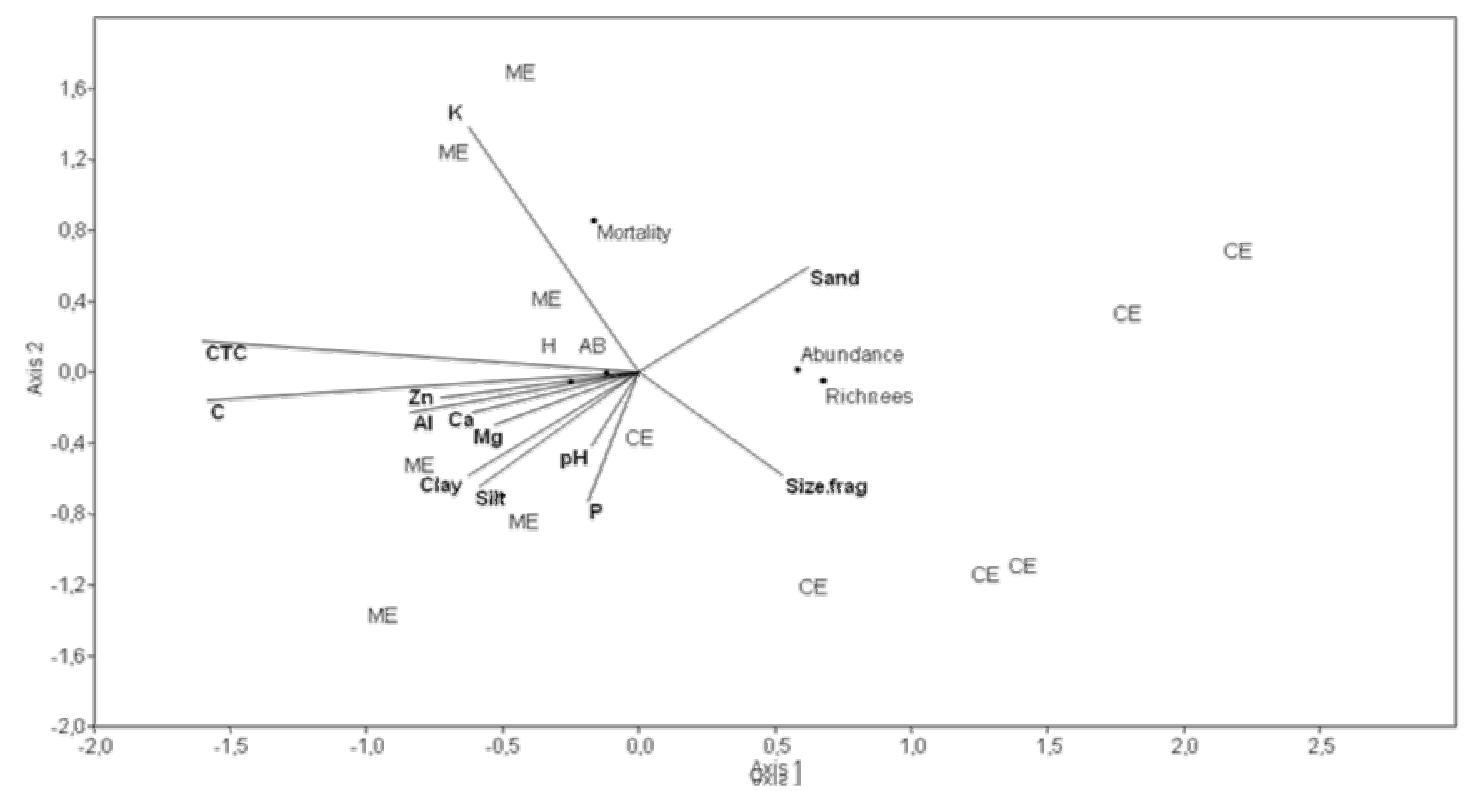

FIGURE 3 Analysis of the canonical components of the forest fragments of Chapadão do Céu with environmental variables and ecological aspects (Richness: $91.35 \%$, Abundance: $6.58 \%$, Mortality: $2.07 \%$, Hmean: $0.001 \%)$.

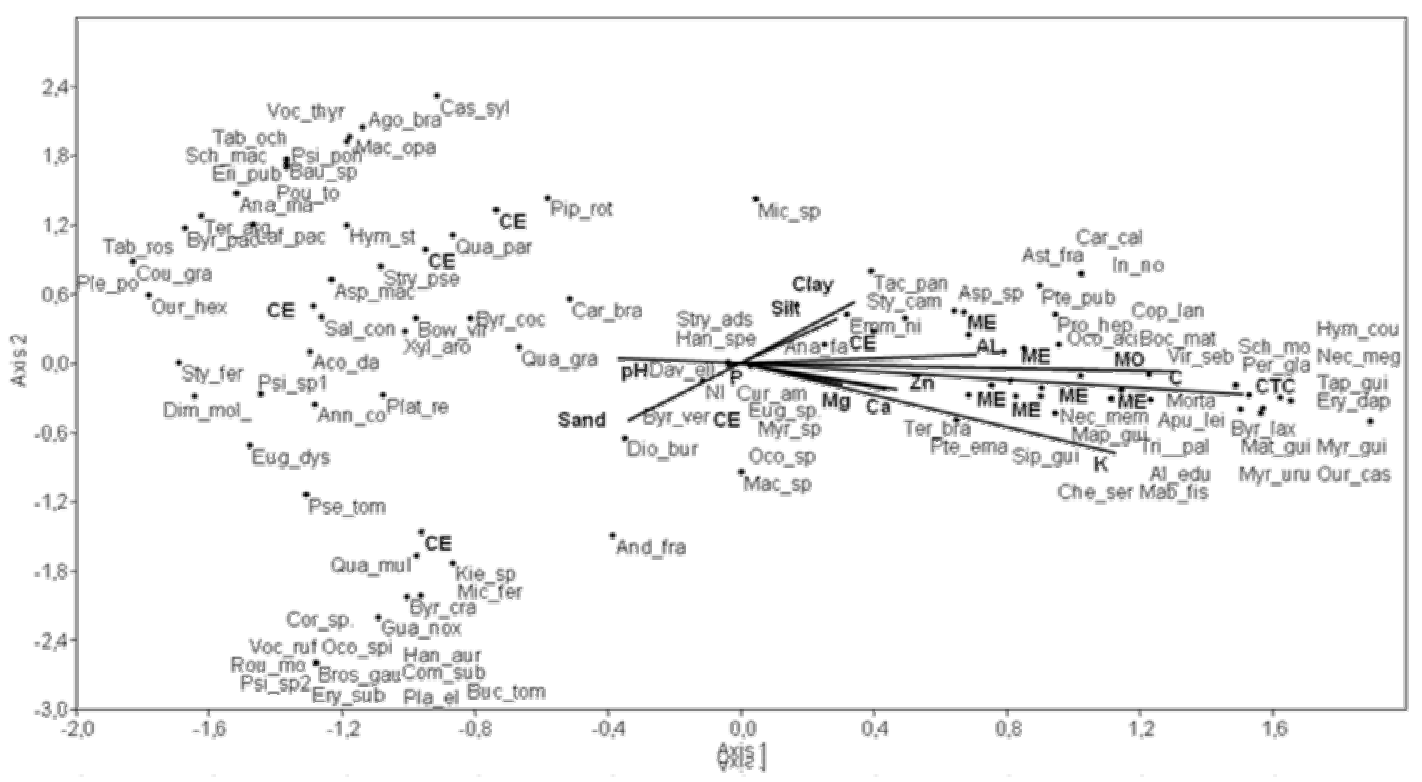

FIGURE 4 Analysis of the canonical components of the forest fragments of Chapadão do Céu with environmental variables and abundance of tree species (Clay: 19.65\%, Silt: 15.55\%, Sand: $11.83 \%$, Ca: 10.44\%, Mg: 9.89\%, Al: 8.86\%, pH: 7.81\%, K: 6.7\%, WM: 4\% and C: 0.001\%). 


\section{DISCUSSION}

Ecological indices reflect differences between areas. In the Seasonal Forest, there is a predominance of few species, but in abundant numbers. In Cerradão, there is a high richness of tree species. This condition probably occurs due to the greater light entry in the Cerradão plot, providing a condition for other seedlings to develop and compete for space. The greatest diversity was 3,326 in Cerradão area and less than 1,195 in small fragment of Seasonal Forest. In this study, the Cerrado area presents diversity indexes compared to areas of conservation unit of the State of Goiás and Federal District, such as Serra de Caldas National Park $\left(H^{\prime}=3.82\right)$, Chapada dos Veadeiros National Park $\left(H^{\prime}=3.49\right)$ and Brasília National Park $\left(H^{\prime}=3.42\right)$ (CARVALHO et al., 2008). The composition of species, the structure of the seasonal forests varies greatly with soil, water and light conditions, as well as between stages of regeneration (BOTREL et al., 2002).

The structural and ecological aspects of the vegetation are used to verify the changes related to the anthropic actions undertaken in the vicinity or modifications of the environment over time. These parameters also reveal the differences of composition among the phytophysiognomies of the Cerrado itself. Adequate information for the use and non-use of certain areas, according to the interest in conservation (Figure 3 and 4).

In the area it is evident the structural difference between Cerradão and Seasonal Forest areas. Characteristics such as average height of vegetation, basal area and volume are significantly higher in forest areas (Seasonal Forest) than in areas of Cerradão. However, the number of individuals and species richness is lower in the Seasonal Forest. Taking as an example, the opening of new areas for cultivation or the choice of suitable areas for conservation, these parameters should be considered.

Future relationships between fragment size and soil use in the environment should be sought to elucidate possible causes for the high mortality of tree species in fragments of seasonal forests. The areas near the border end up becoming brighter, warmer and drier and the species respond in various ways to this phenomenon (MURCIA 1995). Some do not support low moisture, for example, but others benefit, such as some species of vines that have large abundance in the fragment (SILVANETO et al., 2015, VENTUROLI, 2015). The edge effects are linked to loss of species, the richness variation and differentiation of the basal area of the species found on the edge and within the fragment (SCARIOT et al., 2005).

The site with the highest mortality showed the highest levels of potassium (K) in the soil. This relationship may indicate old burnings and forest fires, which turn biomass into ashes, which are rich in inorganic compounds. Once burned trees die directly or weaken, which can lead to death in the long term (1 to 5 years) (FELFILI 2003; CAMARGO et al., 2010).

The Seasonal Forest, unlike Cerradão and Cerrado vegetation restricted sense, does not present direct adaptations to resist the passage of fire, such as coarse bark and seasonal loss of foliage (SCARIOT et al., 2005). The fires modify the structure of the abusive-arboreal vegetation, this directly reflects in the reduction of biomass, occurring the increase of the mortality rate of the individuals.

Patterns in the distribution of the structural features of the Chapadão do Céu tree assembly point to the moment when the plant community is passing. In addition, they can show previous changes, such as fires, irregular deforestation, edge effects and others. In addition, it outlines a current scenario for future comparison of the area (FELFILI \& VENTUROLI, 2000; SILVA-NETO et al., 2015; VENTUROLI, 2015). 
Height, basal area, and volume may indicate whether the amount of individuals with a particular characteristic is a natural pattern for the environment, or has been conditioned due to some anthropogenic change. For the height characteristic, in the areas of Seasonal Forest is within the normal distribution, presenting an expected pattern for forest formations.

The diametrical distribution of both phytophysiognomies has a "J-reverse" pattern, which is expected for a growing forest tending to the climax, where new individuals come in the form of seedlings and regrowths (SCOFORO, 1998). The edaphic characteristics of the soils of the region, together with the structural and ecological characteristics of the forest fragments, show that Cerradão presented the greatest abundance and richness of species, even with soils of low natural fertility. On the other hand, the soil of the Seasonal Forest presented higher amounts of nutrients, as well as higher biomass production with basal area, wood volume and plant height. The seasonal forests have different environmental conditions than those found in Cerradão, such as fertile soils with low water retention, factors that eventually select species more apt to settle in these environments (SILVA \& SCARIOT, 2003).

Seasonal forest soils tend to be more fertile, since they occur generally in shallow soils and under outcrops of rocks with high nutrient content, whereas in Cerradão areas they are older and deeper soils and tend to have a lower fertility and higher concentration of aluminum which reflects on the richness and difference of the basal area of Cerradão and Seasonal Forest species.

The pedological characteristics also show the preference of certain species for the phytophysiognomies. The soil properties in the Cerrado favor the occurrence of a large number of endemic species. In areas of Cerradão and Cerrado, restricted sense is more common Qualea spp., Caryocar brasiliense, Styrax spp, Dimorphandra mollis; Aspidosperma macrocarpon, Vochysia spp, Hancornia speciosa, Annona coriacea, Eugenia desynterica, Acosmium dasycarpum among others, considered typical of this physiognomy. The areas of seasonal forest, present

Protium heptaphyllum, Astronium fraxinifolium, Copaifera langsdorffii, Tapirira guianensis, Nectandra spp. Ocotea spp among others some species can be found easily in both physiognomies, such as Tachigali paniculata, Eugenia spp, Diospyrus spp, Myracrodruon urundeuva e Andira spp.

The soil of the seasonal forests presents a greater availability of nutrients in the soil, as compared to other vegetation, such as Cerradão (MORENO \& SCHIAVINI, 2001), which plays a fundamental role in the distribution and richness of the species that are found in the Seasonal Forest. The species that constitute a plant community exhibit morphological characteristics and physiological responses that are the result of the interaction between soil-plant, which is related to the climatic and edaphic conditions of the environment.

The eigenvalues presented by CCA axes 1 and 2 (0.546 and 0.253) (Figure 4), are considered high for similar studies performed in the Seasonal Forest (BOTREL et al., 2002; MARTINS et al., 2003). In addition, close to those found in studies in the formation of Cerradão (CAMPOS et al., 2006; RODRIGUES \& ARAÚJO 2013). The CCA correlated Copaifera langsdorffii, Tapirira guianensis, Schefflera morototoni with soils of higher fertility and high aluminum content according to other studies of species distribution in the Seasonal Forest (DALANESI et al., 2004; TEIXEIRA \& ASSIS, 2009).

The species that are distributed in soils with low natural fertility, low pH levels and higher sand values, such as Qualea spp., Caryocar brasiliense, Bowdichia 
virgiloides, Xylopia aromatica among others. They presented similar behavior to other studies related to the distribution of species in Cerradão (MARIMON \& HARIDASAN, 2005; SALIS et al., 2006; RODRIGUES, 2009).

\section{CONCLUSION}

The ecological aspects differentiated between the analyzed phytophysiognomies. Cerradão was the one that showed the greatest richness of species in all plots analyzed. On the other hand, the Seasonal Forest obtained the highest values in the structural aspects, as much in the average height as in the average diameter.

The distribution of the species in the analyzed area is correlated to the edaphic characteristics of the place, mainly the chemical characteristics such as natural fertility. This study together with others in the scientific literature will provide subsidies for adequate recovery plans for the Chapadão do Céu region. So that species are consciously chosen so that there is no de-characterization of the original biome.

\section{REFERENCES}

BARROSO, G. M.; PEIXOTO, A. L.; COSTA, C. G.; ICHASO, C. L. F; GUIMARÃES, E.F.; Lima, H.C. Sistemática de Angiospermas do Brasil. Viçosa: UFV. v. 3, p. 309, 1991.

BOTREL, R. T.; OLIVEIRA FILHO, A. D.; RODRIGUES, L. A.; CURRI, N. Influência do solo e topografia sobre as variações da composição florística e estrutura da comunidade arbóreo-arbustiva de uma floresta estacional semidecidual em Ingaí, MG. Revista Brasileira de Botânica, v. 25, n. 2, p. 195-213, 2002. Disponível em: <http://dx.doi.org/10.1590/S0100-84042002000200008>. doi: 10.1590/S010084042002000200008

BRASIL, Ministério do Meio Ambiente. Mapeamento do Uso e cobertura do Cerrado: Projeto Terra Class Cerrado 2013. Sbf. Brasília: MMA, p. 67, 2015. (http://www.dpi.inpe.br/tccerrado/TCCerrado_2013.pdf). Acesso em 12/03/2016.

CABACINHA, C. D.; CASTRO, S. S. Estrutura diamétrica e estado de conservação de fragmentos florestais no Cerrado Brasileiro. Floresta e Ambiente, v. 17, n. 1, p. 51-62, 2010.

CAMARGOS, V. L.; MARTINS, S. V.; RIBEIRO, G. A.; CARMO, F. M. S.; SILVA, A. F. Avaliação do impacto do fogo no estrato de regeneração em um trecho de Floresta Estacional Semidecidual em Viçosa, MG. Revista Árvore, v. 34, n. 6, p. 1055-1063, 2010. Disponível em: <http://dx.doi.org/10.1590/S0100-67622010000600011>. doi: $10.1590 / \mathrm{S} 0100-67622010000600011$

CAMPOS, E. D.; DUARTE, T. G.; NERI, A. V.; SILVA, A. D.; MEIRA-NETO, J. A. A.; VALENTE, G. E. Composição florística de um trecho de cerradão e cerrado sensu stricto e sua relação com o solo na Floresta Nacional (FLONA) de Paraopeba, MG, Brasil. Revista Árvore, v. 30, n. 6, p. 471-479, 2006. Disponível em: < http://dx.doi.org/10.1590/S0100-67622006000300018>. doi: 10.1590/S010067622006000300018 
CARVALHO, F. A.; RODRIGUES, V. H. P.; KILCA, R. V.; SIQUEIRA, A. S.; ARAÚJO, G. M.; SCHIAVINI, I. Composição florística, Riqueza e Diversidade de um Cerrado sensu stricto no Sudeste do Estado de Goiás. v. 24, p. 64-72, 2008. Disponível em: $<$ http://www.scielo.br/scielo.php?script=sci_nlinks\&pid=S2175786020150001000010 0016\&lng=em>

DALANESI, P. E.; OLIVEIRA-FILHO, A. T. D.; FONTES, M. A. L. Flora e estrutura do componente arbóreo da floresta do Parque Ecológico Quedas do Rio Bonito, Lavras, $\mathrm{MG}$, e correlações entre a distribuição das espécies e variáveis ambientais. Acta botanica brasilica, v. 18, n. 4, p. 737-757, 2004. Disponível em: < http://dx.doi.org/10.1590/S0102-33062004000400005> doi: 10.1590/S010233062004000400005

FELFILI, J. M.; VENTUROLI, F. Tópicos em Análise de Vegetação. Comunicações Técnicas florestais. de Brasília, Distrito Federal, v. 2, n. 2, p. 41, 2000. Disponível em: < http://www.scielo.br/scielo.php?script=sci_nlinks\&ref=000105\&pid=S0100$6762200800010001000009 \&$ Ing $=\mathrm{em}>$.

FELFILI, J. M. Fragmentos de florestas estacionais do Brasil Central: diagnóstico e proposta de corredores ecológicos. In: R.B. Costa (Ed.). Fragmentação florestal e alternativas de desenvolvimento rural na Região Centro-Oeste. Universidade Católica Dom Bosco, Campo Grande, Mato Grosso do Sul, p. 138-160, 2003. Disponível em: <http://www.scielo.br/scielo.php?script=sci_nlinks\&ref=000079\&pid=S010084042007 $00040000700012 \&$ Ing $=$ em $>$.

FILIZOLA, H. F. A amostragem de solosIn: M. A. F. Gomes; M. D., de Souza (Eds.). Manual de procedimentos de coleta de amostras em áreas agrícolas para análise da qualidade ambiental: solo, água e sedimentos. Jaguariúna, São Paulo, p. 25-33, 2006.

FRANCESCHINELLI, E. V.; CARMO, R. M.; SILVA-NETO, C. M.; GONCCALVES, B. B.; BERGAMINI, L. The reproductive success of Cabralea canjerana (Vell.). Mart. (Meliaceae) in Atlantic Forest fragments in Brazil. Revista de Biologia Tropical, v. 63, n. 2, p. 515-524, 2015. Disponível em: $<$ http://www.scielo.sa.cr/scielo.php?script=sci_arttext\&pid=S00347744201500020001 $5>$.

FREITAS, W. K.; MAGALHÃES, L. M. S. Vertical structure of the arboreal component under regeneration phase of a deciduous forest fragment, Santa Catarina State, Brazil. Revista Árvore, v. 40, n. 5, p. 781-791, 2016. Disponível em: http://dx.doi.org/10.1590/0100-67622016000500002

IBGE. 2004. Instituto Brasileiro de Geografia e Estatística - Mapa da vegetação brasileira.

Escala

$1: 5.000 .000$.

$<\mathrm{ftp}: / / g e o f t p . i b g e . g o v . b r / m a p a s \_t e m a t i c o s / m a p a s \_m u r a i s / b i o m a s . p d f>$. Acesso em 19/03/2016. 
LOPES, A. S.; GUILHERME, L. R. G. Fertilizantes e corretivos agrícolas: Sugestões de manejo para uso eficiente. Reunião Brasileira de Fertilidade do Solo e Nutrição Mineral de Plantas, v. 20, p. 39-70, 1992.

MARTINS, S. V.; SILVA, N. R. S.; SOUZA, A. D.; MEIRA-NETO, J. A. A. Distribuição de espécies arbóreas em um gradiente topográfico de Floresta Estacional Semidecidual em Viçosa, MG. Scientia Forestalis, v. 64, p. 172-181, 2003. Disponível em: <http://www.scielo.br/scielo.php?script=sci_nlinks\&ref=000102\&pid=S010067622007 00060001800025\&lng=em>.

MARTINS, T. O.; SOUZA, K. R.; OLIVEIRA, F. D.; SILVA-NETO, C. M.; VENTUROLI, F.Por trás das árvores comuns: padrões ambientais de arbóreas menos freqüentes na floresta estacional do cerrado. TreeDimensional, v. 1, p. 42-55, 2016. Disponível em: <http://dx.doi.org/ 10.18677/TreeDimensional_2016_005>. doi: 10.18677/TreeDimensional_2016_005

MARIMOM, B. H. J.; HARIDASHAN, M. Comparação da vegetação arbórea e características edáficas de um cerradão e um cerrado sensu stricto em áreas adjacentes sobre solo distrófico no leste de Mato Grosso, Brasil. Acta Botanica Brasilica, v. 19, n. 4, p. 913-926, 2005. Disponível em: <http://dx.doi.org/10.1590/S0102-33062005000400026>. doi: 10.1590/S010233062005000400026.

MELO, A. T. O.; COELHO, A. S. G.; PEREIRA, M. F.; BLANCO, A. J. V.; FRANCESCHINELLI, E. V. Genética da conservação de Cabralea canjerana (Vell.). Mart. (Meliaceae) em fragmentos florestais de Mata Atlântica na APA Fernão Dias. Revista Árvore, v. 39, n. 2, p. 365-374, 2015. Disponível em: < http://dx.doi.org/10.1590/0100-67622015000200016>. doi: 10.1590/010067622015000200016.

MORENO, M. I. C.; SCHIAVINI, I. Relação entre vegetação e solo em um gradiente florestal na Estação Ecológica do Panga, Uberlândia (MG). Revista Brasileira de Botânica, v. 24, n. 4, p. 537-544, 2001. Disponível em: < http://www.scielo.br/pdf/rbb/v24n4s0/9475.pdf>.

MURCIA, C. Edge effects in fragmented forests: implications for conservation.Trends in Ecology \& Evolution, v. 10, n. 2, p. 58-62, 1995. Disponível em: < http://www.scielo.br/scielo.php?script=sci_nlinks\&ref=000126\&pid=S0102330620120 0010001900024\&Ing=em>. doi:10.1016/S0169-5347(00)88977-6

MYERS, N.; MITTERMEIER, R. A.; MITTERMEIER, C. G.; FONSECA, G. A.; KENT, J. Biodiversity hotspots for conservation priorities. Nature, v. 403, p. 853-858, 2000. Disponível em:

http://www.scielo.br/scielo.php?script=sci_nlinks\&ref=000101\&pid=S01039016200700040000600028\&lng=PT>.

RIBEIRO, J. F.; WALTER, B. M. T. Fitofisionomias do bioma Cerrado. In: SANO, S.; RIBEIRO, J. P.; ALMEIDA, S. P. (Eds.). Cerrado: ecologia e flora. Embrapa Cerrados, Planaltina, Distrito Federal, v. 1, p. 151-199, 2008. AGRARIAN ACADEMY, Centro Científico Conhecer - Goiânia, v.3, n.06; p.12 2016 
<http://simposio.cpac.embrapa.br/simposio_pc210/projeto/palestras/capitulo_11.pdf> Acessado em 23/03/2016.

OLIVEIRA-FILHO, A. T.; JARENKOW, J. A.; RODAL, M. J. N. Floristic relationships of seasonally dry forests of eastern South America based on tree species distribution patterns. In: R.T, PENNINGTON; G.P. LEWIS \& J.A. RATTER (Org.). Neotropical savannas and dry forests: Plant diversity, biogeography and conservation. Boca Raton: CRC Press, p. 151-184, 2006. Disponível em: < http://www.scielo.br/scielo.php?script=sci_nlinks\&ref=000107\&pid=S0104$7760201400020000100017 \&$ lng $=\mathrm{em}>$.

RODRIGUES, R. F.; ARAÚJO; G. M. Estrutura da vegetação e características edáficas de um cerradão em solo distrófico e em solo mesotrófico no Triângulo Mineiro. Bioscience Journal, v. 29, n. 6, p. 2013-2029. 2013. Disponível em: <http://www.seer.ufu.br/index.php/biosciencejournal/article/viewFile/22090/13454>.

RODRIGUES, R. F. Características do solo e estrutura fitossociológica de espécies arbóreas em dois cerradões no Triângulo Mineiro. 2009. Disponível em: <https://repositorio.ufu.br/bitstream/123456789/13316/1/dis.pdf>.

SALIS, S. M.; ASSIS, M. A.; CRISPIM, S. M. A.; CASAGRANDE, J. C. Distribuição e abundância de espécies arbóreas em cerradões no Pantanal, Estado do Mato Grosso do Sul, Brasil. Brazilian Journal of Botany, v. 29, n. 3, p. 339-352, 2006. Disponível em: <http://dx.doi.org/10.1590/S0100-84042006000300002>. doi: 10.1590/S0100-84042006000300002.

SCARIOT, A; FREITAS, R. S.; NETO, E. M.; NASCIMENTO, M. T.; OLIVEIRA, L. C. de; SANAIOTTI, T.; SEVILHA, A. C.; VILELA, D. M. Vegetação e Flora In: RAMBALDI, D. M.;OLIVEIRA, D. A. S. DE. (Eds.). Fragmentação de Ecossistemas: Causas, efeitos sobre a biodiversidade e recomendações de políticas públicas. Ministério do Meio Ambiente. Secretaria de Biodiversidade e Florestas, Brasília, p.104-326, 2003. Disponível em: < www.mma.gov.br/estruturas/chm/_arquivos/fragment.pdf>.

SCOFORO, J. R. S. Manejo florestal. UFLA/FAEPE, Lavras. 1998.

SILVA, J. M. C.; BATES, J. M. Biogeographic patterns and conservation in the South American Cerrado: a tropical savanna hotspot. BioScience, v. 52, p. 225-233. 2002 Disponível em:

http://www.scielo.br/scielo.php?script=sci_nlinks\&ref=000193\&pid=S0031104920120 $0240000100056 \& \operatorname{lng}=$ es $>$.

SILVA, J. F.; FARINAS, M. R.; FELFILI, J. M.; KLINK, C. A. Spatial heterogeneity, land use and conservation in the cerrado region of Brazil. Journal of Biogeography, Oxford, v. 33, n. 3, p. 536-556. 2006.

SILVA-NETO, C. M.; VENTUROLI, F.; GONÇALVES, B. B.; FERREIRA, G. A. Incremento diamétrico de Protium heptaphyllum (Aubl.) Marchand em floresta estacional semidecídua sob manejo, em Pirenópolis, Goiás, Brasil. Interciencia, v. 
40 ,

p. 564-569,

2015.

Disponível

em:

$<$

http://www.redalyc.org/pdf/339/33940176010.pdf>.

SILVA, L. Á.; SCARIOT, A. Composição florística e strutura da comunidade arbórea em uma floresta estacional decídua em afloramento calcário (Fazenda São José, São Domingos-GO, Bacia do Rio Paranã). Acta Botânica Brasílica, v. 17, n. 2, p. 307-315, 2003.

SIQUEIRA, K. N; FERREIRA, H. D.; TOSCANO, T. G.; SANTOS, J. H.; SILVA, M. G. Quais espécies de árvores estão na borda da floresta estacional do cerrado?. TreeDimensional, v. $1, \quad$ n. 1 p. 56-66, 2016. Disponível em: <http://dx.doi.org/10.18677/TreeDimensional_2016_006>.

doi: 10.18677/TreeDimensional_2016_006.

TEIXEIRA, A. P.; ASSIS, M. A. Relação entre heterogeneidade ambiental e distribuição de espécies em uma floresta paludosa no Município de Cristais Paulista, SP, Brasil. Acta Botanica Brasilica, v. 23, p. 843-853, 2009. Disponível em: < http://www.scielo.br/pdf/abb/v23n3/v23n3a25.pdf>

VENTUROLI, F.; FRANCO, A. C.; FAGG, C. W. 2015. Tree diameter growth following silvicultural treatments in a semi-deciduous secondary forest in Central Brazil. Cerne, v. 21, n. 1, p. 117-123, 2015. Disponível em: <http://dx.doi.org/10.1590/01047760201521011204>. doi: 10.1590/01047760201521011204.

VENTUROLI, F. Inventário florestal: Princípios para uma aplicação prática. Ed. CEGRAF/UFG, Goiânia, 40 p. 2015.

WALTER, B. M. T. Fitofisionomias do Bioma Cerrado: sínteses terminológicas e relações florísticas. Tese (Doutorado em Ecologia) - Programa de Pós-Graduação em Ecologia, Universidade de Brasília, Brasíla, 2006. Disponível em: <http://www.pgecl.unb.br/images/sampledata/arquivos/teses/2000a2010/2006/Bruno $\% 20$ M.T.\%20Walter.pdf>. 